\title{
COUNSELING GIFTED STUDENTS: A WEB-BASED COURSE
}

\author{
I'm not sure that I was thinking about collaboration as a research topic until I realized its \\ importance in the context of this course.
}

Dr. Elizabeth Shaunessy, Assistant Professor, Department of Special Education at the University of South Florida, reflected as she looked back on the progress of her graduate course EGI-6416 (Consultation, Counseling, and Guidance Skills for Gifted Students). Overall, the web-based course seemed to be going very well. Students were generally participating actively in weekly sessions. The quality of work being submitted was generally good — and some of it outstanding, especially a number of the student-authored case studies of real world counseling situations. Nonetheless, at times she felt that students were not grasping the full scope of the counseling challenge-and the importance of not trying to "go it alone". What had gotten her thinking about this subject were some difficulties she was encountering in getting students for form effective work groups. In just the previous week, she had dealt with a student trying to avoid group work by seeking out a project that no one else had chosen, one who had alienated fellow group members by attempting to assume control of a group without consulting them, and one who had repeatedly ignored attempts to contact her. All this in spite of the fact that the exercise- the course final exam-represented over a third of their grade and it had been specifically stated that no one working alone would get a grade of more than $70 \%$.

It was clear that part of the challenge Shaunessy was facing was a result of the context of the course. EGI6416 was part of a 5 course sequence that could be used by teachers to get state certification in gifted education, as well as being part of a Master's in Education program. The entire program was taught using distance learning, since virtually all the students were K-12 teachers who worked full time and could not come to USF. This meant that few of the classmates ever met, either before or during the course. "How do you form cohesive groups in such an environment?", she wondered. On the other hand, without high levels of interactivity in the course, she might as well be teaching a correspondence course.

\footnotetext{
This case was prepared for the purpose of class discussion, and not to illustrate the effective or ineffective handling of an administrative or classroom situation and is copyrighted by the Informing Science Institute. Permission to make digital or paper copy of part or all of these works for personal or classroom use is granted without fee provided that the copies are not made or distributed for profit or commercial advantage AND that copies 1) bear this notice in full and 2) give the full citation on the first page. It is permissible to abstract these works so long as credit is given. To copy in all other cases or to republish or to post on a server or to redistribute to lists requires specific permission and payment of a fee. Contact Publisher@InformingScience.org to request redistribution permission.
}

As the coordinator of the Gifted Education program, Shaunessy recognized that the issues she was currently facing had implications far beyond those of the present course. Currently, hers was the only such program offered throughout the Florida state university system. That situation, however, would likely not last forever. She needed to ensure the program remained both beneficial and engaging for its participants. If it did not, she recognized that location was no longer a dependable impediment to competition. 


\section{USF College of Education}

With over 44,000 graduates, USF's College of Education (COEDU) played an important role in training teachers throughout the state of Florida and nationally. Among some of its most impressive achievements are included:

- It graduated more educators than any other university in Florida.

- It was the 6th largest College of Education in the country and was accredited by NCATE and other specialty area educational organizations.

- It ranked in the top 60 among all graduate schools of education according to U.S. News and World Report.

- During 2003, CODEDU faculty received over 23 million in external grants and contracts in support of their research and professional service efforts (Source: COEDU web site, "Message from the Dean", accessed on 1/29/2005 from http://www.coedu.usf.edu/main/welcome.html).

The COEDU was organized into eight departments: 1) Adult, Career and Higher Education, 2) Childhood Education, 3) Educational Leadership and Policy Studies, 4) Educational Measurement and Research, 5) Psychological and Social Foundations, 6) School of Physical Education, Wellness and Sports Studies, 7) Secondary Education, and 8) Special Education.

Each department offered a variety of degree programs and certificate programs. At the graduate level, the student body was dominated by individuals working as full time teachers. In addition to being motivated by the desire to increase their professional skills, completion of these programs could lead to two highly tangible benefits: endorsements required to teach in certain areas and a union-negotiated pay scale which provided substantial rewards for degrees and certifications.

Because so many of its students were working full time, COEDU was a leader in distance learning (DL) at USF. As of late 2004, it listed three graduate programs entirely online: M.A. in Career and Technical Ed, M.A. in Gifted Education, and Ed.S. in Instructional Technology. In addition, many of the requirements of other programs could be fulfilled through distance education.

\section{COEDU Gifted Education Master's Program}

Shaunessy's gifted education M.A. program was offered within USF's Special Education department, which offered degrees at the bachelors, masters and doctoral level. To the outsider, this positioning might seem incongruous - within a department whose other programs included behavior disorders, mental retardation, special education, specific learning disabilities, and varying exceptionalities (Exceptional Student Education). But, as a matter of practice, gifted education shared many characteristics in common with other special education areas, including:

- The desirability of offering specialized programs to allow students to maximize their potential

- The need to acquaint teachers with the specific challenges often faced by the student

- The importance of addressing the emotional consequences that can stem from the student's feeling of being "different", and

- The challenges faced in dealing with parents and other teachers who interact with the student without fully understanding the student's particular needs. 
Within Florida, how gifted education was implemented varied by county and grade level. In some counties, students were assigned to full-time gifted classrooms, taught by certified teachers. In other counties, students were provided access to "pull out" gifted programs. In these, students might attend classes in specific subject areas (e.g., math and science, language arts) with a gifted instructor, while attending their remaining classes with regular students. Hybrid approaches were also used in some counties, with students periodically being shuttled to other sites for gifted enrichment days once a week or more.

The "pull out" and "enrichment day" approaches to gifted education, while offering benefits to the student, were frequently the source of conflict between parent, teacher and student. For example, should a student be held responsible for homework assigned in classes missed while he or she was attending pull out gifted sessions? How was grading to be coordinated between regular and gifted class teachers? How did regular students react to students being pulled out of classes? In addition, parents of gifted studentsregardless of program type--could be extremely difficult to deal with (with the pronounced desire to micromanage their child's education being commonplace). Difficulties with parents could manifest themselves in many ways. On the one hand, some parents were notoriously eager to ensure gifted placement for their child who, on the basis of test scores, might not qualify_-going so far as to employ highly paid outside professionals to dispute the results of school-administered tests. On the other hand, some parents objected to the larger workload that typically accompanied gifted placement, and could be reluctant to accept the notion that their child was not at the top of the class.

The M.A. in Gifted Education (see Exhibit 1) included courses in both instructional techniques beneficial to gifted students and in techniques for addressing the challenges of gifted education. Within the Master's program, a 5 course sequence served as the basis of a certificate in gifted education, the prerequisite for receiving a state gifted teaching endorsement. While the gifted certificate was described as being available for "teachers, administrators, parents, school psychologists, and others interested in gifted endorsement", in practice the makeup of the student body was much narrower. The typical student was working as a full-time teacher at a public elementary or middle school in Florida. The vast majority of students (97\%) were women, ranging in age from early 20s to mid-30s, and most had already had some exposure to gifted students. A typical student might take 1 to 2 courses a semester. Expected time to complete a certificate ranged from 1 to 2 years, while a complete Master's degree was projected to take from 3 to 4 years, part time.

Although the M.A. program was first offered in the 1970s, it has been transformed recently, as explained by Shaunessy:

The face-to-face M.A. degree in gifted began in the 1970s and then around 2000, when districts could offer staff development courses in the endorsement areas, including gifted, the enrollment in the face-to-face program at USF began to decline greatly, and the program was nearly wiped out. Thus, the move to an online format... The new format attracted people, mostly from outside the Tampa Bay area, that didn't have access to local endorsement courses in gifted. The word has gotten out about the program, which includes 15 hours toward the FL endorsement in gifted, which are also part of the 36 hour gifted MA.

The forces leading to the transformation of the program to DL had an important practical impact: students enrolled in the program were far more distributed geographically than would be typical for a USF class, even a DL class. That meant face-to-face meetings-between students or between professor and students-were rare, if they occurred at all. 


\section{Elizabeth Shaunessy}

Dr. Elizabeth Shaunessy joined USF in Fall 2003 as a tenure track Assistant Professor, shortly after completing her doctorate. As summarized in Exhibit 2, prior to receiving her doctorate, she had taught gifted students (principally in the language arts at the high school level). In 1999, she completed national board certification, a demanding program of coursework and teaching assessment viewed as a highly significant achievement among educators.

Shaunessy was hired specifically to act as the Coordinator of the Gifted Education program. In that capacity, she had major responsibility for program design and course content. In addition, she also advised all of the students in the M.A. and certificate programs, who would email her regularly for information regarding program changes and other related questions.

Shaunessy was responsible for teaching all the courses relating to Gifted Education. In 2004, the courses she taught included EGI-5051 (Nature and Needs of the Gifted Student), EGI-6232 (Advanced Educational Strategies for Gifted Students), EGI-6416 (Consultation, Counseling, and Guidance Skills for Gifted Students), EGI-6943 (Supervised Practicum for Gifted Education), EGI-6936 (Seminar In Special Populations of Gifted Students) and directed independent study courses. Her courses, which typically had 15-30 students, formed the backbone of the gifted program. All of the courses were delivered online.

Shaunessy noted that her transition to distance learning had not been entirely expected, and that the move had not been made without effort:

I had joined previous professors at my doctoral institution in delivering chats for undergraduate courses, as I thought it might be possible that I'd end up teaching some courses online. Then this job, which is totally online, became available. I teach no face-to-face classes, which has been a challenge since I am really a people person. Now when people come to my office I usually try to keep them around so I can revel in the face to face contact (if I like the conversation). I've had to learn so much just to get to a place where I feel somewhat comfortable making choices about the design of online instruction.

No one could argue with the results of the program, however. Since the time when Shaunessy had joined as coordinator, student enrollment had continued to grow. In order to keep up with the course demand, one adjunct a semester had to be hired. Furthermore, in 2005 the College of Education had taken the step of advertising for a second faculty position in the gifted area. This was quite unusual, since few programs - either statewide or nationally—had sufficient demand to justify more than one faculty member in the gifted area.

\section{EGI-6416}

During the fall semester of 2004, Shaunessy was teaching EGI-6416 (Consultation, Counseling, and Guidance Skills for Gifted Students). She viewed this course as being particularly critical in a gifted teacher's education because it addressed many areas were teachers were naturally weakest-either by inclination or by training. She also noted, wryly:

My preparation did not include coursework in counseling or guidance for the gifted, but this is not unusual in our field, as few institutions offer such courses. 


\section{Course Objectives}

Two particularly important skills to be developed by the course were the ability to work effectively in collaboration with others and the ability to counsel productively (students, parents and other teachers). Reliance on collaboration often ran counter to the teacher's desire to be "in command" of his or her classroom. While this independence could be practical in many traditional teaching situations, it was definitely an obstacle to effective teaching in a pull out or enrichment gifted program. Because such programs were part time in nature, their effectiveness depended almost entirely on how well gifted and standard requirements were coordinated. Such coordination could not be achieved in a vacuum.

A teacher's ability to counsel productively, and to diagnose and solve problems, was often hampered by perceptions (fostered by numerous gender-oriented works in popular psychology) that being supportive equated to listening uncritically. As a consequence, in discussions between gifted and regular teachers, important information regarding a student was often withheld to avoid the appearance of being unsympathetic (by virtue of suggesting a solution rather than simply providing encouragement). Because gifted teachers in part time programs were so dependent upon regular teachers for background information and suggestions, such patterns of communication could delayed diagnosis and action by months or even years. Gifted teachers needed to understand how to modify these patterns on both sides. They needed to learn how to offer potential solutions in a manner that was not perceived as being overly domineering. They also needed to learn how to probe for suggestions from teachers who preferred to nod silently for fear of appearing unsupportive.

\section{Course Requirements}

To lead students towards the goals of fostering both teamwork and critical thinking skills, EGI-6416 had an unusual, and highly innovative, design. The course was built around 3 requirements (see Exhibit 3), each of which emphasized a different aspect of the course:

- Weekly discussions (30\%): Required students to discuss readings and course activities on a weekly basis. These discussions were set up in the "Discussion Board" area of the Blackboard course management system used by USF, and averaged 60+ postings per week in a 20 person class. Exhibit 4 provides a screen capture of part of the Fall 2004 Discussion Board page.

- Counseling Project (35\%): Required students to write up a case study of a situation in which a gifted student with whom they were familiar was facing a significant challenge. Because this project would require a substantial number of interviews on sensitive subjects, it was only available to certified teachers who had access to gifted students. An alternative project, conducting a literature review, was available as an alternative.

- Final Exam (35\%): In one of the most innovative aspects of the course, the final exam involved taking case studies developed by students in the Counseling Project assignment and developing recommendations, as a group, on how the situation should be handled. Students were expected to form their own groups to complete the final, and the instructor then created a Group Area in Blackboard to facilitate the collaboration project. These areas contained Discussion Boards, File Sharing areas and locations for archiving online text chats, as shown in Exhibit 5. Students were then instructed to limit their intra-group communications to Blackboard facilities (chat, discussion groups), allowing the instructor to monitor individual participation within the group.

With respect to alignment with the course objectives, the weekly discussions were intended to help foster the types of critical thinking skills that were vital to effective counseling, and to help students learn to communicate differences in opinion in a supportive fashion. They also served to provide a sense of presence and ongoing activity that could sometimes be lost in a distance learning environment that heavily relied on static content such as readings. The counseling project was intended to encourage 
students to adopt the counseling persona. Gathering the type of data necessary to develop a case study also represented a close parallel with the type of data gathering needed in the diagnosis and treatment of the problems encountered by gifted students. The final exam represented the capstone of the course. Not only were counseling and diagnostics skills to be developed by the exercise, collaboration was also a major part of the exercise. Indeed, students failing to collaborate, e.g., by refusing to join a group or through being "fired" by their teammates, could achieve a grade no higher than $70 \%$ on the exercise.

\section{Course Progress: mid- November 2004}

By mid-November 2004, students had met all the EGI-6416 course requirements except for the final examination. Generally, Shaunessy had been very pleased by their progress. The students had met her expectations in many regards, and had far exceeded them in others. Even the weekly discussions had served their purpose: keeping the class engaged (although not necessarily providing the most engrossing reading).

There was one wrinkle to the weekly groups that Shaunessy had not anticipated. From week one, some students started posting anonymously-meaning the post was made without any identification as to who made it. This option was provided, on the advice of another faculty member, to provide students with a sense of safety. These postings also created a bit of a dilemma, however. On the one hand, she was not inclined to prohibit such postings (which Blackboard allowed her to do using a simple setting), since she wanted students to feel comfortable as they discussed issues that were often sensitive in nature. On the other hand, the practice was both confusing and a bit annoying. Confusing, because students were being graded on weekly participation — and being anonymous precluded any credit being assigned. Annoying, because a key course objective was to foster collaborative behaviors. How can a spirit of collaboration be present when members of the group refuse to identify themselves? As it turned out, other students in the course apparently felt the same way_and sent emails to Shaunessy proposing that the right to post anonymously be terminated. About midway through the course, she changed the posting policy to permit only postings with names_-anonymous posts were no longer an option.

The other challenge presented by the weekly groups was that of grading the discussions. Because the Blackboard environment provided no obvious means of assigning grades to individual postings, keeping track of student participation often required rereading discussions at least twice: first, to get the flavor of the discussion and make comments, and second, to assign grades. Since weekly discussions were weighted so heavily (30\% of total course grades), there was no obvious solution to get around this.

The second component of the course requirements, the counseling project, had left Shaunessy feeling extremely pleased-bordering on ecstatic (in some cases). Nearly all of the student-generated case studies had been quite presentable, and several had been exceptional. She had been particularly pleased, and somewhat surprised, by the range of sensitive subjects that had emerged in the cases. These included situations involving medication and learning disabilities, potential parental abuse, sexual identity issues, gender conflicts, peer pressure and conflict between teachers.

After the students had submitted their initial versions, she selected the 5 most promising for use as a final exam. She then contacted the students who wrote the cases under consideration and asked them for specific changes/additions/revisions. This process took about 3 weeks to complete. A representative example of such a revised case (minimally disguised to ensure the participants in the case could not be identified) is presented in Exhibit 6.

The high quality of the counseling projects served to alleviate one of Shaunessy's concerns about the course design - the fact that student cases were to be used as the basis of the final examination. Whereas 
she had been somewhat nervous about whether or not enough high quality student projects would be available for final exam purposes, these fears proved to be groundless. She easily identified five studentauthored case studies that would make appropriate final exams. Indeed, she could have used several others-had the objective of the exam not included requiring students to work as a team in performing their analysis.

\section{The Final Exam}

The first stage of the final exam involved posting the five student cases to be used to the "Course Documents" area of Blackboard, and setting up a parallel Discussion Group with each case as a separate thread. Students were to sign up for a case by posting a reply to the desired thread. Groups were supposed to form on a first come, first served basis, with students selecting the cases of the greatest interest to them. Students were not allowed to sign up for case that they wrote.

In designing the exam, Shaunessy had intended that the organization into groups be accomplished with as little instructor intervention as possible. The rationale here was that students were to arrange their collaborative efforts through their own initiative-exactly as they would need to do in a real world setting. As the process of team formation unfolded, however, a number of unexpected problems started to emerge. Among these:

- Some groups seemed to be forming based on the nature of the group members, rather than the nature of the case.

- Instructions on group size (intended to be 3 or 4) were being ignored, with one group of 2 and one group of 6 forming, based on signups. While she conceded that part of this was caused by overly permissive instructions (see Exhibit 7) — which specified groups of 2-4 in size-there was no way the larger group should have formed.

- One student had indicated that her choice of group (the 2 person group) was motivated entirely by the desire to collaborate with as few people as possible.

- One group (the 6 person group) had started to exhibit severe conflict before the group formation process had even been completed.

While all of these problems were matters of concern, the last was taking up the largest amount of her attention. She had already received an email from a student who had complained that she had emailed all the other people who had signed up and they had ignored her. Meanwhile, four of the individuals who had signed up had indicated that they had already mapped out a strategy for working together, and had little interest in adding additional participants-particularly one who had previously developed a reputation for assertiveness, i.e., the one whose email message had been ignored. Finally, there was a student who had signed up but who had ignored all attempted contacts - from the first student, from the group of four, and from the instructor. What, precisely, was to be done about that?

In addition, as she looked ahead to the exam itself, she began to wonder if she could expect all her instructions to be followed. Her experiences with the class and the fact that group formation had been dominated by personalities, and not case content, suggested that channels of communications outside of Blackboard (e.g., the phone or instant messaging) were being utilized by students to communicate with each other. How likely was it that these channels would be abandoned for a collaboration exercise? And should she really expect or want them to be? 


\section{Reflections}

As Shaunessy considered the final exam situation, she realized that the problems she faced were largely of her own making. Had her course employed a less innovative structure, the need to address such interpersonal issues would have disappeared. Even without dropping the final exam, she could have easily eliminated the current set of problems by assigning students to groups-at random, if necessary. But, she also wondered if there was an educational value to making students address the problems inherent in collaboration; a "teachable moment" in the jargon of the trade. Or were the problems the students faced so specific to online communications that they had little relevance to the real world?

Abstract thoughts aside, she realized that she needed to decide on a plan of action immediately if students were to complete their exam according to her timetable. That meant she needed to decide how to address the six person group and the two person group. How directive did she want to be in resolving these issues? And what impact could her choices have on such mundane issues such as teaching evaluationswhich tended to be filled out only by the most satisfied and dissatisfied students in a DL environment.

Her experiences in the course also raised some larger issues to think about, as she considered how the course should be run when it was next taught. Among these:

- Given the problems she had encountered in getting students to collaborate, were there any changes to the course design that should be made to enhance their skills in that area?

- Were there any changes that could be made to reduce the amount of work required to keep track of weekly participation - while ensuring that students were aware that it was being monitored?

- Should she consider introducing new techniques for communicating into the course, to add to the realism of the collaboration process?

The last of these came to mind because she had just heard that USF would be pilot testing a software product called Elluminate in 2005, and that she could have access to it. That software provided a virtual classroom environment with capabilities that included voice chat, text chat, whiteboard and shared applications, to name a few. Would providing such a communications environment to students enhance collaboration? Or would the cost of encouraging its use-and the accompanying loss of ability to monitor student participation — outweigh the gains of richer interactions between students?

Finally, there was the question that all tenure-track (but untenured) faculty face: to what extent was inflicting serious harm on her career prospects (at a Research I university) by lavishing so much time on her teaching? And, let there be no doubt, EGI-6416 was insatiable in its demands for instructor time as it was currently designed. 


\section{Exhibit 1: USF Gifted Education Master's Program}

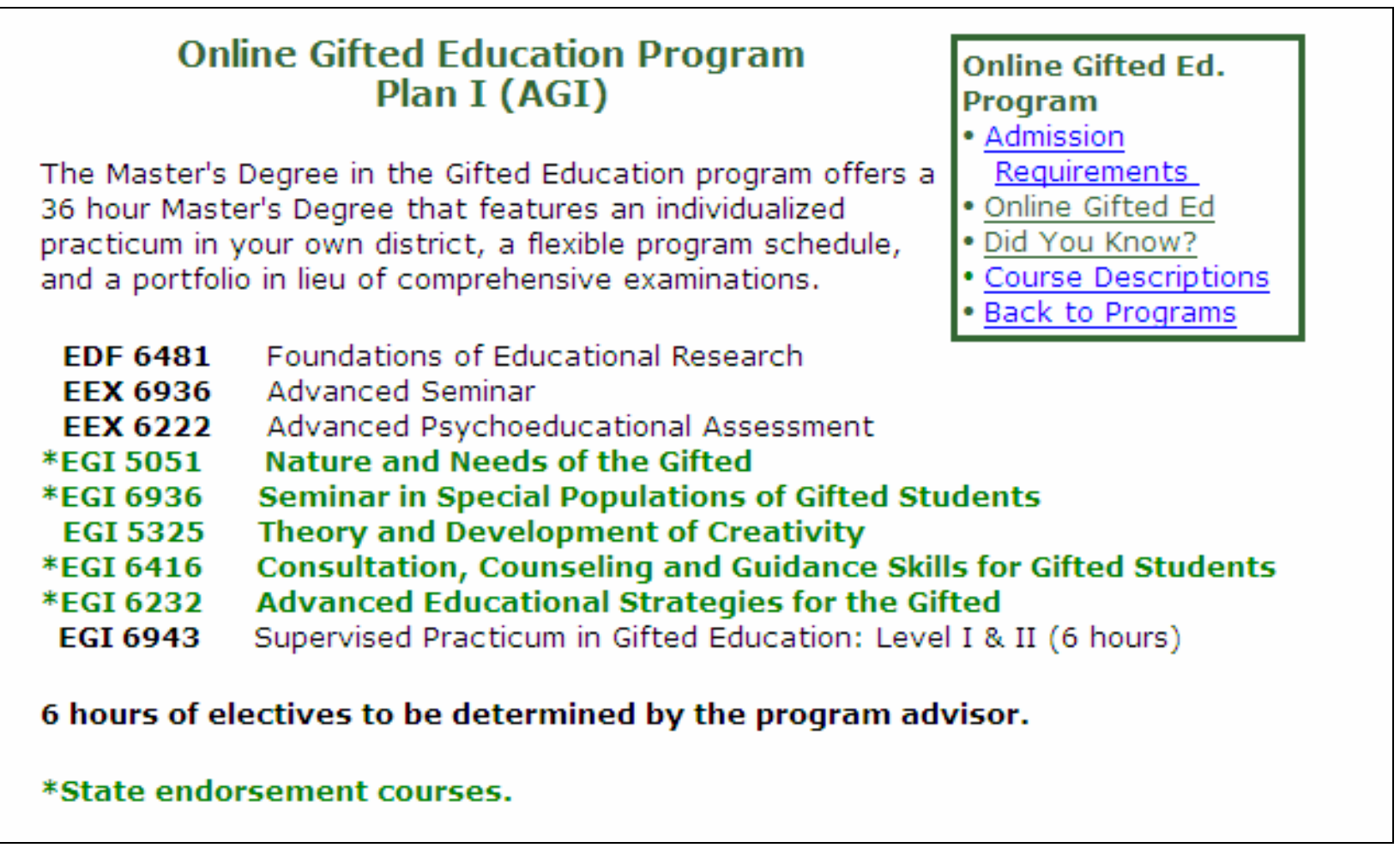

Source: Retrieved on 1/29/05 from http://www.coedu.usf.edu/deptspeced/Gifted\%20Ed/giftedprog.html 


\section{Exhibit 2: Shaunessy Biography}

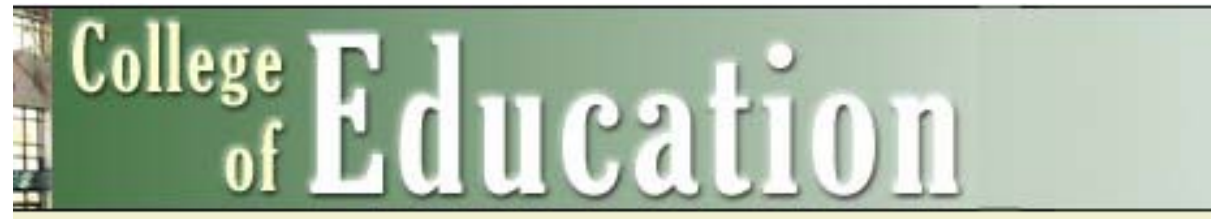

S. Elizabeth Shaunessy, Ph.D. Assistant Professor 813-974-7007 Shaunessy@tempest.coedu.usf.edu

Dr. Shaunessy is an Assistant Professor in the Department of Special Education, and serves as the Coordinator of the Gifted Education Program

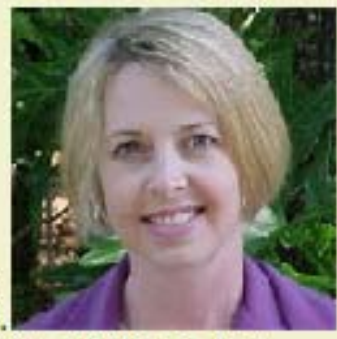
She received her B. A. in English from the University of Miami, her M.A. in English from Florida State University, and her Ph.D. in Special Education with an emphasis in Gifted Education from The University of Southern Mississippi. At USF, Dr. Shaunessy teaches in the online gifted program, which offers courses leading to the graduate certificate and master's degree in gifted education. Her research interests include gifted children with Asperger Syndrome, culturally diverse gifted learners, the use of technology in gifted education, and public policy in gifted education. Prior to teaching in higher education, Dr. Shaunessy was a high school teacher of Advanced Placement Language and Composition and other courses in secondary language arts, where she taught gifted learners, general education students, and students with disabilities. In 1999 she earned National Board Certification in English Language Arts for Adolescents and Young Adults.

Source: Retrieved on 1/29/05 from http://www.coedu.usf.edu/main/departments/sped/EShaunessy.html 


\section{Exhibit 3: EGI-6416 Course Requirements}

\section{Required assignments:}

All work must be placed into the appropriate folder in "assignments" section of this course. Do not email your assignments or place them in the digital drop box. Only electronic copies will be accepted. If you do not have Microsoft Word, please save your document as an html file and then post it in the appropriate folder. The assignments folder is a new feature in Blackboard, which allows the instructor to see the names of all students who have submitted their work and the time it was submitted. Due to the volume of emails the instructors receive and due to technical difficulties with the digital drop box, the assignments folder is now required unless otherwise noted.

\section{Weekly grade: $30 \%$}

Students are expected to complete assignments, assigned readings, and participate in group discussions and activities. Our course weeks run from Monday through Sunday. Postings to assignments MUST be made no later than Sunday evening at $11 \mathrm{pm}$ for full credit.

\section{Weekly Grade Rubric}

100

Student a thorough explanation of thoughts, reactions to ideas presented. Connects ideas from previous chapters, teaching, reading, living, etc. to the quote. Personal reflections/reactions included.

85

Student provides some explanation of ideas, reactions, thoughts in the discussion. Appears to be summarizing the readings and not offering authentic personal connections with the ideas selected.

70

Very limited discussion or no discussion of assigned material included. Missing elements of the assignment or has not connected elements of the assignment.

$\mathbf{0}$

No work turned in by assigned date.

\section{Counseling Project: 35\%}

Students will select either 1) the student counseling project or 2) review of literature. This project will be due Sunday, October 31 at 11 pm. Please place assignment in the folder marked "counseling project/review of literature.”

\section{Option 1: Student Counseling Project}

This choice is only available to certified educators employed by a school since it requires students to have contact with a child. Other students who are not certified teachers teaching in a school setting must choose the literature review.

This activity is designed to help you practice effective listening and counseling skills with a gifted or talented student; therefore, it will be necessary to plan at least six separate meeting times. A permission form has been provided (in Course Materials) for use in acquiring permission from the student's guardians to access school and assessment information as needed. Please select a student who is either identified gifted, perceived as gifted, or has missed the identification criteria but is still perceived as gifted by an informed adult. You are urged to select a student whose giftedness or talents may be accompanied by a social, academic, or emotional challenge. Thus, the student may be in need of some additional support in understanding and dealing with aspects of his/her life. Realize that an individual's acceptance of his/her 
own problem will accelerate the counseling process. For the purposes of this assignment, you may wish to select a student who already has acknowledged a need for improvement or counseling. Please do not use the student's real name.

There are several informal activities as well as formal inventories (see Course Documents, Resources folder) provided that can be used to help you get to know the student better. Sometimes this may be accomplished in a more meaningful manner outside of the school environment. A copy of a parent and student inventory are available in the Course Documents section for assessing perceived stress in the student's life, as is a self-concept measure. A growth contract is provided that will help you collaboratively determine an area for affective growth or achievement. Problem areas may address such issues as: procrastination, low self esteem, siblings relationships, poor social skills, underachievement, perfectionism, or lack of motivation. The selected area should serve as the basis for a series of counseling sessions during which you may use discussions, activities, and shared experiences to help the student reflect on fulfilling the growth contract.

Your case profile should begin with a narrative introducing basic information about the student, pertinent family data, school and or community information, your reason for selecting the student, and the nature of the problem identified. Subsequent documentation in your case profile should summarize what transpired at each meeting, anecdotal observations, responses to activities, and insights that you gained from each session. Your final summation should include an objective report on the student's progress as well as a reflective analysis of your own skills and reactions throughout the process. You will submit your report via the assignment folder for this project in Blackboard. Please read Chapters 4 and 11 before beginning this project. Also, students should make every effort to avoid serious issues such as those on page 91.

\section{Option 2: Review of Literature}

Review a minimum of five journal articles on a specialized topic that you select such as underachievement, over excitabilities, perfectionism, self-concept, sibling relationships, or attitudes toward the gifted. Your article analysis should include: 1 ) the purpose of the article; 2) the rationale the authors provide for the significance of the issue being examined/discussed; 3) the methodology used in the article; 4) the findings reported by the authors; 5) the conclusions developed by the authors; and 6) your interpretation of the significance of this article to the guidance and counseling needs of gifted students. You will also be required to cite these articles in APA 5th edition reference format. You will be expected to submit your reviews to the instructor via the assignment folder labeled "review of literature." Your write-up should include your analysis of how the article(s) agree or disagree with the material in this course. Please follow the guidelines for reviewing articles found in the COURSE DOCUMENTS section of Blackboard.

\section{Final exam: 35\%}

The student will work collaboratively to design a counseling plan based upon a given scenario. The students will be expected to demonstrate proficiency in addressing the social/emotional needs of the gifted learner gleaned from the readings, materials, and discussions included in this course. The scenario and directions will be posted near the end of the course and will be due on Sunday, December 5 at $11 \mathrm{pm}$. Place final exam into assignment folder marked "final exam." Specific guidelines for this project will be available in week 13. (November 12).

Source: EGI-6416 Fall 2004 Syllabus 


\section{Exhibit 4: EGI-6416 Discussion Board}

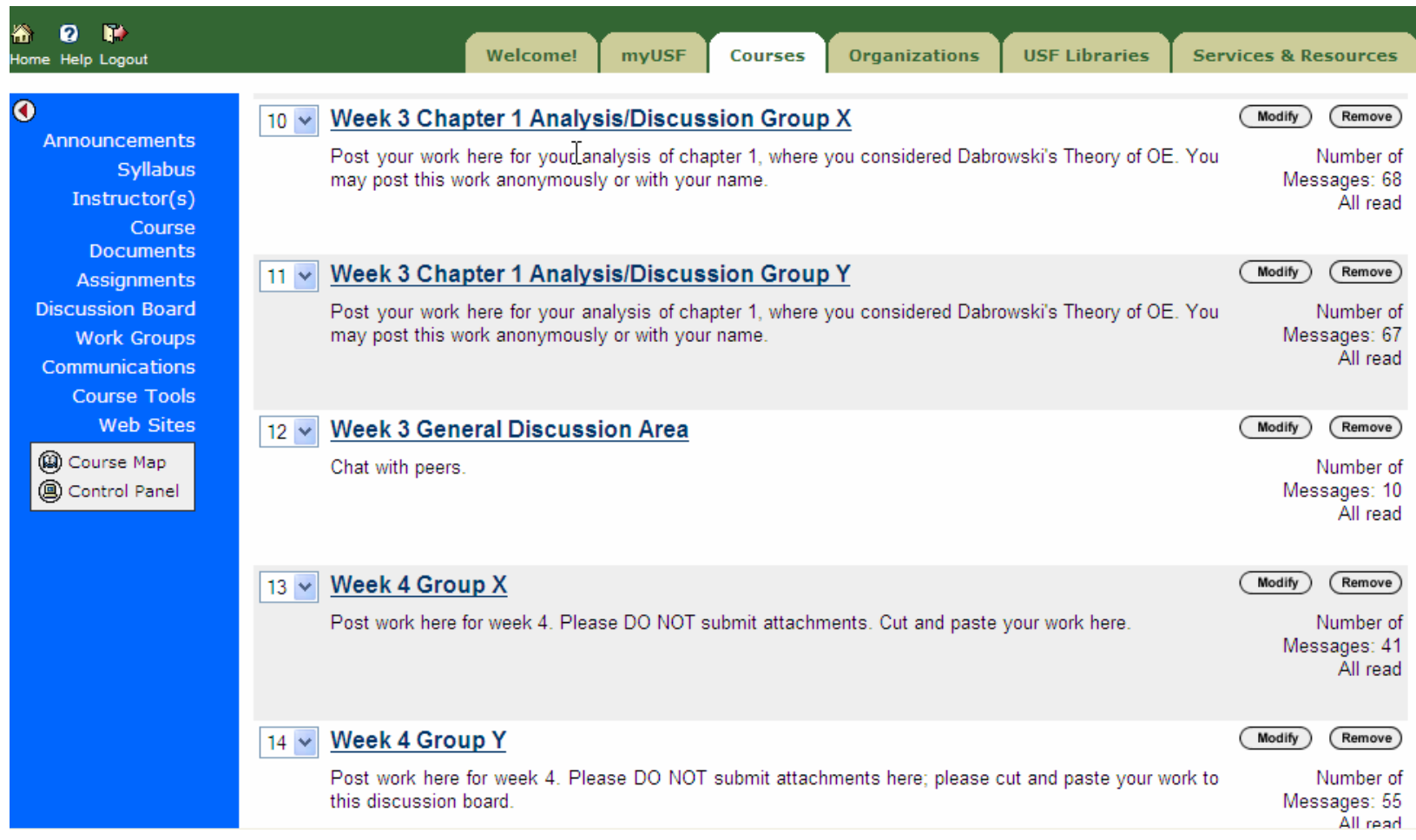




\section{Exhibit 5: Group Collaboration Area}

\section{Group Page: Group 4}

$\checkmark$ Group Discussion Board

Use the Group Discussion Board for debates and conversations

Collaboration

Participate in Collaboration Sessions.

File Exchange

Exchange files with group members.

$\checkmark$ Send Email

Send email to one or more group members.

$\checkmark$ Group Members

Name

Email

[Names and email addresses withheld for privacy reasons] 


\title{
Exhibit 6: Example of a Student-authored Case Study
}

\author{
Cody's Concerns \\ by Anonymous student author (with permission)
}

Cody is a male fifth grade student identified as gifted. He is currently $10 \frac{1}{2}$ years old and of Caucasian decent. Cody, his mother, father, and high school brother (also in the gifted program) live in their home as a middle-class family.

In Kindergarten, Cody was evaluated using the Woodcock-Johnson and a Connor's behavior scale. The Woodcock indicated that in Kindergarten he was currently functioning in the high range, yet the Connor's indicated several areas of concern with oppositional behaviors and hyperactivity. As a result of the Kindergarten screenings and assessments, in the first grade, Cody was placed on medication for ADHD. Medication is continued to date, at times making him sleepy as dosages are adjusted due to growth.

When Cody was in 3rd grade his parents sought private counseling for him and the private counseling team developed a behavior plan for him to address identified noncompliance school issues such as refusing to complete tasks, physical aggression to objects (kicking desk, breaking pencils, crumpling assignments) and verbal aggression. This plan was in place for most of third grade and not initiated in fourth grade due to lack of need. At the time of the behavior plan initiation in third grade, there was no identification of a disability nor was an IEP developed at the school level.

Cody was staffed into the gifted program last spring as a 4th grader after being referred for services by his fourth grade teacher. At the time of his formal evaluation for gifted, Cody scored a 130 full scale IQ, which qualified him for services using the WISC III. There is a 22 point difference between his verbal score of 117 and performance score of 139 . Of the specific subtests, the weakest score was in comprehension and the strongest were picture arrangement and block design.

When he began receiving services in the spring of fourth grade, his father and teachers expressed concern about Cody's emotional state during his transition from leaving his regular classroom to the gifted pull-out classroom, which he attended 1 full day each week. This gifted pull-out group consisted of 16 Caucasian students: 7 males and 9 females. Before leaving home he refused to eat and claimed of being too ill to attend school. Later in his regular classroom, he would cry and refuse to leave the classroom while sitting at his desk with his hands buried in his head. His classroom teacher was highly effective in meeting his emotional needs as well as motivating classroom performance. A team teaching approach to connect the gifted classroom and basic education classroom were implemented until Cody felt comfortable with the new placement. Cody met one-on-one before the school day began for about 5 minutes with his classroom teacher to review any concerns about what was being taught in the classroom that day. When the gifted teacher arrived to pick him up for the class, the teacher would share the concerns. Most of the concerns were about missing recess, making up work, not having snack, being afraid of making a mistake, new situations with different classmates and forgetting something in his classroom.

Although these concerns had been addressed at the staffing, which he attended, new concerns arose each day. The gifted teacher would then provide the flexibility for Cody to return to his regular classroom at any time he felt uncomfortable, however, he was asked to write down the reason in a journal for the gifted teacher before leaving. Although the parents suggested attending the gifted class with him and experiencing the gifted classroom by his side, this was discouraged by the school administration and both teachers. In approximately seven weeks, the time spent in the resource room gradually increased until Cody was able to stay in the gifted classroom for the full day, and after the third week it was no longer necessary for the gifted teacher to walk him to the gifted classroom. Currently there is not an adjustment concern with leaving the classroom to the gifted classroom.

This year, Cody has experienced difficulty in adjusting to the 5th grade classroom. The regular education class is composed of 21 students, 10 males and 11 females, of which two are Hispanic. The class spent the first three weeks of school in Media Center while their portable classroom was being constructed. School has been cancelled for a total of 10 days thus far due to three separate hurricanes. His father had a conference with the gifted education 
teacher; she indicated that his academic performance is acceptable in that setting. Cody's parents are concerned that Cody is not completing his class assignments in his fifth grade classroom and in their opinion, feel that too much work is required to be made up after the day in the gifted resource classroom. Cody's father called the gifted teacher after Cody was required to sit in from recess the day following gifted to take a test he missed during the gifted day. The general education teacher feels that if Cody had completed his other assignments in a more timely manner, he could have made up the test before recess time. It is the classroom teacher's opinion that he spends too much time daydreaming and not paying attention instead of staying focused on the assignments. Of the three students from this particular class that attend gifted, Cody is the only student who has these completion challenges.

In collaboration with the classroom teacher and the gifted teacher, it was found that no accommodations were being made for Cody's ADHD concerns. His classroom teacher requires all assignments to be completed in regular education, even if the student misses the assignments will in the gifted classroom In two incidences in which his mother had completed two regular classroom homework assignments for him, the mother was consulted via the telephone and Cody spent three 30 minute recess detentions to complete the assignments on his own. Cody's mother indicated that the assignments were too long, so to assist him she recorded the information he provided, but this was not acceptable to the regular education teacher. The classroom teacher confidentially mentioned to the gifted education teacher that "This student and his parents had taken up too much of her time, and it was only October."

After two weeks of increasing concerns, Cody' parents requested a Child Study team meeting with their parent liaison, school guidance counselor, classroom teacher, gifted teacher, and staffing specialist. Cody's parents requested that he be tested for a learning disability, although the classroom teacher and gifted teacher did not share the same recommendation. Both teachers feel that Cody is capable of completing the assignments, but he appears to choose which assignments to complete and how much effort to exert in completing them. The parents, especially the mother, feel that assignments with writing are "torture" for him to complete and take too long. His parents also brought a prescription from his pediatric physician for a 504 plan to accommodate his ADHD. The staffing specialist initiated the testing for learning disabilities, and would not initiate a 504 plan unless a learning disability is found.

In the meantime, the classroom teacher and parents have agreed to keep a daily communication log in which incomplete assignments are recorded so that accurate information is collected. The gifted education teacher also consulted the county gifted plan, which specifies that students receiving gifted services are not required to make up entire classroom assignments while at the gifted class, even though the county plan asks that students not make-up work from their classroom while attending a gifted session. The classroom teacher agreed that all assignments would not have to be made up, however, certain vital skill assignments would require completion.

Since the meeting 10 days ago, there has been some improvement in Cody's assignment completion. However, his parents are still concerned with the two-hour-per- night homework assignments, especially given Cody's a) inability to complete assignments in class, b) his decreased interest in attending school, and c) his waning interest in his school assignments, even in science, which is his favorite subject 


\section{Exhibit 7: Final exam group formation instructions}

$1 \vee$ Select your case here $\$$

After you have read the directions for the final exam (which will be available November 5 ), then select a case (which will be available November 5 and found in the course documents section) and put your name below your selection in this folder. Post your selection by November 14 at $11 \mathrm{pm}$.
Modify Remove

Number of Messages: 28

All read

Revisit this folder to locate others who would like to work on the case you've selected, and identify others so that you have a group of 2-4 people working collaboratively on this case. Once your group has identified who will work together, please visit the final exam groups folder and post this to the instructor along with your work plan as outlined in the final exam directions folder, located in the course documents section. Post this group by Wednesday, November 17 at $11 \mathrm{pm}$ 


\section{Biographies}

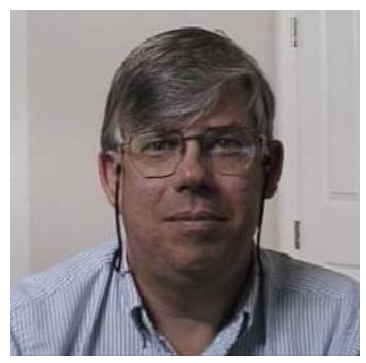

Grandon Gill is an Associate Professor in the Information Systems and Decision Sciences department at the University of South Florida. He holds a doctorate in Management Information Systems from Harvard Business School, where he also received his M.B.A. His principal research focus is in the area of IS education, and he has published many articles describing how technologies and innovative pedagogies can be combined to increase the effectiveness of teaching across a broad range of IS topics. Currently, he teaches programming, database and managerial courses to both undergraduate and graduate students.

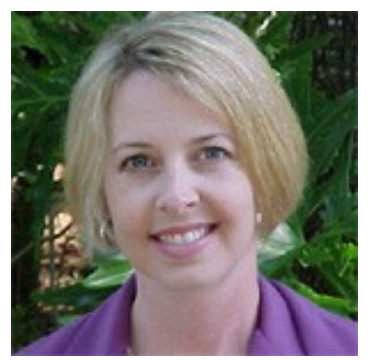

Elizabeth Shaunessy is an Assistant Professor in the Department of Special Education at the University of South Florida, where she also serves as the Coordinator of the Gifted Education Program. She received her B. A. in English from the University of Miami, her M.A. in English from Florida State University, and her Ph.D. in Special Education with an emphasis in Gifted Education from The University of Southern Mississippi. She currently teaches in the online gifted program, which offers courses leading to the graduate certificate and master's degree in gifted education. Her research interests include gifted children with Asperger Syndrome, culturally diverse gifted learners, the use of technology in gifted education, and public policy in gifted education. 